\title{
Studies on Process Standardization and Quality Evaluation of Ginger Ale
}

\author{
H.W. Deshpande ${ }^{1}$, Mukesh Belwal ${ }^{1}$, S.D. Katke ${ }^{1 *}$ and N.M. Tamboli ${ }^{2}$ \\ ${ }^{1}$ Dept. of Food Microbiology \& Safety, College of Food Technology, \\ VNMKV, Parbhani, India \\ ${ }^{2}$ Dept. of Agricultural Engineering, College of Agriculture, VNMKV, Parbhani, India \\ *Corresponding author
}

\section{A B S T R A C T}

\section{Keywords}

Ginger ale, Natural

fermentation,

Controlled

fermentation,

Zingiber officinale,

Rosc, Alcoholic

Brewed Ginger ale

Article Info

Accepted:

10 June 2019

Available Online:

10 July 2019
Ginger ale is a type of beer brewed from malted barley using a warm fermentation with a strain of brewer's yeast. Ginger ale commonly contains water, sugar, ginger extract, lime and other spices. The objective of this study was to modify traditional Ginger ale formulation, to produce a beer like beverage with substitution of hops by ginger and incorporation of malt and yeast at various proportions under natural and controlled fermentation and to evaluate the chemical, microbial and sensory properties of the beverage. Ginger ale was made by natural fermentation and by partially controlled fermentation, followed by pasteurization and were analyzed chemically for $\mathrm{pH}$, titratable acidity, total soluble solids and for alcohol (ethanol) content during a four-day fermentation period. Colour and turbidity of the ales were determined using the spectrophotometer. Sensory evaluations of the samples were conducted. Ethanol concentration of the Ginger ale produced by natural fermentation was lower than that of produced by controlled fermentation, but the colour was darker and turbidity deeper. Organoleptic assessment confirmed that unhopped Ginger ale prepared using the controlled fermentation was generally acceptable.

\section{Introduction}

Ginger (Zingiber officinale Rosc.) (Family: Zingiberaceae) is an herbaceous perennial, the rhizomes of which are used as a spice. India is a leading producer of ginger in the world and Ginger is cultivated in most of the states in India. However, states namely Karnataka, Orissa, Assam, Meghalaya, Arunachal Pradesh and Gujarat together contribute 65 per cent to the country's total production (Jayashree et al., 2014). Maharashtra is one of the leading producers of ginger (Salunkhe et al., 2014). Ale is a type of beer brewed from malted barley using a warm fermentation with a strain of brewer's yeast (Rahman, 2010). Compared to lager yeasts, ale yeast ferments more quickly, and often produces a sweeter, fuller-bodied and fruiter taste. Ginger ale is carbonated, sweetened beverage produced in two versions: alcoholic brewed Ginger ale or a carbonated soft drink flavored primarily with ginger and sweetened with sugar or artificial sweeteners. The traditional method of producing Ginger ale results in a beverage 
that is variable due to the quality of the raw materials, the natural fermentation microflora and the non- standardized processing method (Pambianchi, 1999). As a result, the quality of the final product is inconsistent. Since the quality of a fermented beverage depends on the fermenting micro-organisms, the use of natural microflora results in a product of variable quality (Berry, 1995). However, controlled fermentation produces a product that is consistent in quality. To achieve consistent quality, it is important to know the properties of the fermenting organisms, thereby optimizing the fermentation process. To date, no documentation exists on a standard manufacturing process, the organisms and microbial changes involved and the biochemical changes occurring during the manufacture of Ginger ale. The objective of this study was to modify traditional Ginger ale formulation to produce a beer like beverage with substitution of hops by ginger and incorporation of malt and yeast at various proportions under natural and controlled fermentation and to evaluate the chemical, microbial and sensory properties of the drink.

\section{Materials and Methods}

\section{Raw material}

Fresh ginger (Zingiber officinale Roscoe) rhizomes and fresh lemon (Citrus limonum) were purchased from a local market. Barley, sugar and other required ingredients were also purchased from local market.

\section{Method}

The sample materials used in this work are fresh ginger rhizomes, barley malt, lemon juice, yeast (Saccharomyces cerevisiae), grinded sugar and other spices. The investigation was carried out with various formulations of ginger, malt and yeast under natural and controlled fermentation and results (chemical, microbial and sensory analysis) were recorded. The various formulations made are presented in Table 1.

\section{Preparation of ginger ale by natural fermentation}

Fresh ginger rhizomes were hand-peeled and hand-grated to obtain a homogenized mixture. Boiling water $(1 \mathrm{~L})$ was added to the grated ginger $(120 \mathrm{gm})$ in a stainless steel pot. The mixture was allowed to cool to $35^{\circ} \mathrm{C}$ at room temperature $\left(25-32^{\circ} \mathrm{C}\right)$ for about 30 minutes before lemon juice $(30 \mathrm{ml})$ was added. The $\mathrm{pH}$ of the mixture was reduced to 4.5 by the addition of cream of tartar. The total soluble solids were increased to $13^{\circ}$ Brix by dissolving sugar into the mixture. The mixture was poured into a plastic vessel, covered with a lid and left for $24 \mathrm{~h}$ at room temperature to extract the ginger aroma and for sedimentation of ginger particles. The mixture was then racked into a fermentor vessel, lidded and left to ferment for $48 \mathrm{~h}$ at room temperature. The fermented mixture was vacuum-filtered, hand-bottled $(250 \mathrm{~mL})$ and capped tightly. An air space of $2.5 \mathrm{~cm}$ was left in the bottle. The mixture was fermented for a further $24 \mathrm{~h}$ at room temperature before pasteurization in a water bath at $73^{\circ} \mathrm{C}$ for 20 minutes. Three batches of bottled Ginger ale of varying ginger concentration $(2 \%, 3 \%$ and $4 \%$ ) were prepared using the procedure described. The other parameters were kept constant. Ten semi-trained panelists conducted a sensory evaluation of these beverages to determine the preferred concentration of ginger. This process was repeated using the preferred concentration of ginger $(3 \%)$, but varying the concentration of sugar $\left(11,13\right.$ and $\left.15^{\circ} \mathrm{B}\right)$ to determine the preferred level of sweetness. Finally, a batch of Ginger ale was prepared containing the preferred concentration of ginger $(3 \%)$ and sugar $\left(13^{\circ} \mathrm{B}\right)$. 
Preparation of ginger ale by controlled fermentation

For this process, the mixture containing the ingredients (with additional barley malt and spice mix) was pasteurized $\left(73^{\circ} \mathrm{C}, 20\right.$ minutes) in a stainless steel pot. Re-hydrated yeast solution $(1 \mathrm{gm})$ was added to the mixture after it had cooled to $35^{\circ} \mathrm{C}$. The remaining stages in the process of fermentation, clarification, packaging and pasteurization were unchanged from those of the natural fermented method (Fig. 1).

\section{Results and Discussion}

The results of the preliminary test that determined consumer preference for ginger and sugar in Ginger ale showed that of the three sugar concentration levels, Ginger ale with sugar concentration of $13^{\circ} \mathrm{Brix}$ was preferred to those of 11 and $15^{\circ} \mathrm{Brix}$. Sugar concentration of $11^{\circ} \mathrm{Brix}$ was reported as not sweet enough, while $15^{\circ}$ Brix was too sweet. The Ginger ale containing 3\% of ginger extract was preferred to ales containing $2 \%$ (too little flavour) and 4\% (too pungent). Objective measurements of colour and turbidity (absorbance) indicate greater turbidity (275-300nu) and darker colouration of the ales made by natural fermentation compared to that of ales made by the controlled fermentation (Table 2). Beer after fermentation shows significant turbidity due to the presence of yeast and the cellular tissue comminuted during the malt processing (Benitez et al., 2013). To produce a clear beverage with good visual appearance the colloidal particles must be removed (Fleet and Siebert 2005). Members of the panel rated more favourably to the lighter colour and less turbidity by the scores of 7.6 (controlled) to 7.2 (natural) for general appearance, 8.1 (controlled) to 7.9 (natural) for taste and 7.1 (controlled) to 6.9 (natural) for mouth feel of the beers made by controlled and natural fermentations respectively. The fact that these quality attributes were not significantly different in both ales shows the high variability in preference and the lack of a standard formulation for the production of Ginger ale.

The proximate composition of Ginger ales from natural fermentation showed that the moisture content of the beverages ranged from 87.520 to $88.890 \%$. The sample with the lowest moisture content was those containing $2.5 \%$ ginger. A decreasing trend in the moisture content with increasing concentration of ginger in the samples was observed. High moisture content makes beverage suitable as a refreshing and quenchthirsting product which is characteristic of good beverage although is an indication of short shelf life. This is similar to the report given by (Osuntogun and Aboaba, 2004). The protein content of ginger $(12.60 \%)$ has contributed significantly to the increase in protein content of beverage. The observation shows a progressive significant decrease in the protein content with increasing ginger concentration in the sample. This may be attributed to the effect of heat process involved in the extraction which might have destroyed some amino acids with consequent reduction in total nitrogen content of the resulting beverage (Oluwaniyi et al., 2009). The lipid content of ginger $(18.20 \%)$ has contributed significantly to the increase in fat content of beverage though the beverage is not a good source of fat. The observation shows a progressive significant decrease in the fat content with increasing ginger concentration in the sample. This might be attributed to the effect of direct heat on fat soluble components of the beverage during the process of extraction (Koekemoer et al., 2009). The $\mathrm{pH}$ of the freshly prepared beverage samples with ginger was found to be nearly neutral while the total titratable acidity (TTA) was found to be in between $5.8-6.1 \%$. 
This is an indication that the beverage is less acidic which may be advantageous to patients with stomach and peptic ulcer and other related problems. The observation reveals that the beverage is neutral suggesting the need for inclusion of preservative to extend its shelflife. Comparative study of the chemical compounds obtained for naturally fermented Ginger ale and controlled fermented Ginger ale presented in table 3 . The moisture content of the samples ranged from 87.153 to 89.004. The protein content was found higher in controlled fermented samples ranged from 0.300 to $0.812 \%$ than natural fermented samples. The protein content was higher as there was increase in concentration of barley malt and ginger extract from 5 to $15 \%$ and 3 to $5 \%$ respectively. Similar observations were found for crude fat and carbohydrate content in samples. The low $\mathrm{pH}$ value of 4.1 observed for sample $\mathrm{E}$ could be due to the metabolic activities of contaminating microorganisms particularly lactic acid bacteria that play a role in the production process. Maintenance of hygienic conditions in the laboratory may have caused the $\mathrm{pH}$ of the samples $\mathrm{H}$ and I to be higher i.e. 5.0 and 5.4 respectively. The titratable acidity of samples decreased from 1.08 to 0.82 percent lactic acid for $\mathrm{E}$ and I sample respectively, with a corresponding increase in $\mathrm{pH}$ from 4.1 to 5.4. Thus the titrable acidity (TA) had showed promising trend of deceasing along with increase in $\mathrm{pH}$ of the samples as we increase the proportion of barley malt. The calories of the samples ranged from 35 to $54 \mathrm{Cal} / 100 \mathrm{~g}$. It was found that controlled fermented samples had more calorific values then natural fermented samples. This might be attributed to the effect of barley malt and more of residual total sugar in controlled fermented samples then natural fermented samples. The higher calorific values suggested increased nutrition and instant source of energy from the controlled fermented samples.
Comparative study of the quality parameters obtained for naturally fermented and controlled fermented Ginger ales is presented in table 4. The decrease in total soluble solids from 13 to $8^{\circ}$ Brix is linked to more metabolic activities by yeast and other microflora. Sample E and F were naturally fermented; it showed less conversion of sugar into alcohol (ethanol). The TSS imparts pleasant taste to the beverage and the $\mathrm{pH}$ gives slightly acidic taste to the food. Specific gravity had shown the trend of decreasing as there was increase in yeast concentration and proportions of barley malt from sample E to I. The alcohol (ethanol) content of the samples showed increasing parameters as we increase the concentration of yeast from 0 to $1.5 \%$. It may be attributed to more utilization of sugars by metabolic activity of yeast and thereby more conversion of sugars to alcohol from sample E to I i.e. 0.50 to $2.57 \%$. Both the specific gravity and the total soluble solids of the fermenting mixtures showed the expected decline as sugars were utilized for yeast metabolism, which produced alcohol under anaerobic conditions. Lewis and Young reported similar results for fermenting beverages. This culminated in greater alcohol production by the fourth day of fermentation, revealing the advantage of controlled over natural fermentation for the production of beverages.

The bacteria, yeasts and moulds were absent in the boiled water due to their destruction by heat and in the sugar used. However, the ginger and the lemon juice had variable counts of yeasts, moulds, lactic acid bacteria and other aerobes. Even the yeast sample contained $4.5 \times 10^{3} \mathrm{cfu} / \mathrm{g}$ of sample. Thus the initial count of lactic acid bacteria per gram of the mixture under controlled fermentation far exceeded the number in the mixture fermented by the natural fermentation. The higher initial lactic acid bacteria count resulted in greater activity of the bacteria 
observed during controlled fermentation and the greater production of acid, depicted by lower $\mathrm{pH}$, than observed for the ale under natural fermentation. Rapid multiplication of yeasts and lactic acid bacteria occurred within the first 48 hours of both natural and controlled fermentation due to adequate nutrients, availability of oxygen in the headspace and the ambient temperature. However, this soon tapered off after day two, due to the production of alcohol and the decline in $\mathrm{pH}$ and dissolved oxygen during the course of fermentation (Table 5). The pasteurized product was free of bacteria and yeasts, which suggests that the temperature/time combination, assisted by alcohol content and acidity, was sufficient to destroy the micro-organisms in the beer. Beattie (1970) reported that pasteurization was necessary to stop fermentation, which, if allowed to continue, causes carbon dioxide build-up in the bottle, which blows the cap. Also, the flavour of the bottled Ginger ale changes and becomes more alcoholic, more acidic and less sweet, if the microorganisms are not destroyed by pasteurization (Amerine et al., 1980).

Organoleptic evaluation of beverage samples prepared with various formulations showed that the sample $\mathrm{G}$ scored highest for overall acceptability followed by sample $\mathrm{E}$ and sample I was found to be least acceptable. Consistency and taste are desirable for Ginger ale production. Use of filtration for spice mix gives the beverage a smooth mouth feel as well as contributes to its uniform sediment distribution. The quality of Ginger ale is monitored by determining its taste, aroma and thus acceptability to consumers. Good quality Ginger ale is light yellow in colour, with a sour taste from lemon. Ginger ale is considered spoilt if there is settling of the beverage, excessive sourness and foaming. Spoilage is dependent on the quality of raw materials used, fermentation duration (over or under fermentation), cross contamination and storage conditions (high temperature).

Table.1 Formulation of Ginger ale

\begin{tabular}{|c|c|c|}
\hline Samples & Formulations & Type of fermentation \\
\hline A & $1.0 \%$ ginger extract & Natural \\
\hline B & $1.5 \%$ ginger extract & Natural \\
\hline $\mathbf{D}$ & $2.5 \%$ ginger extract & Natural \\
\hline $\mathbf{E}$ & $3 \%$ ginger extract & Natural \\
\hline $\mathbf{F}$ & $4 \%$ ginger extract & Natural \\
\hline $\mathbf{G}$ & $3 \%$ ginger, $\mathbf{5} \%$ barley malt, $\mathbf{1 \%}$ yeast & Controlled \\
\hline $\mathbf{H}$ & $3.5 \%$ ginger, $\mathbf{1 0 \%}$ barley malt, $\mathbf{1 \%}$ yeast & Controlled \\
\hline I & $\mathbf{5 \%}$ ginger, $\mathbf{1 5 \%}$ barley malt, $\mathbf{1 . 5 \%}$ yeast & Controlled \\
\hline
\end{tabular}

Table.2 Spectrophotometric absorbance of Ginger ales

\begin{tabular}{|l|c|c|c|}
\hline \multicolumn{1}{|c|}{ Ginger ale samples } & Absorbance at 430 nm & Absorbance at 700 $\mathbf{~ n m}$ & Colour \\
\hline Natural Fermentation & 0.505 & 0.166 & $\mathbf{6 . 4}^{\mathbf{0}}$ \\
\hline Controlled Fermentation & 0.182 & 0.069 & $\mathbf{2 . 3}^{\mathbf{0}}$ \\
\hline S.E \pm & 0.00014 & 0.00043 & $\mathbf{0 . 0 1 4 4}$ \\
\hline C.D. at 5\% & $\mathbf{0 . 0 0 0 4 3}$ & $\mathbf{0 . 0 0 1 3}$ & $\mathbf{0 . 0 4 3 4}$ \\
\hline
\end{tabular}


Table.3 Comparative study of the chemical compounds obtained for naturally fermented and controlled fermented Ginger ales

\begin{tabular}{|c|c|c|c|c|c|c|c|c|}
\hline Samples & $\begin{array}{c}\text { Moisture } \\
\%\end{array}$ & $\begin{array}{c}\text { Protein } \\
\%\end{array}$ & $\begin{array}{l}\text { Crude } \\
\text { fat } \%\end{array}$ & $\begin{array}{c}\text { Carbo- } \\
\text { hydrates } \\
\%\end{array}$ & pH & $\begin{array}{c}\text { TTA (\% } \\
\text { LA) }\end{array}$ & $\begin{array}{c}\text { Residual } \\
\text { Total Sugar } \\
\quad(g / L)\end{array}$ & $\begin{array}{c}\text { Cal } \\
/ 100 g\end{array}$ \\
\hline $\mathbf{E}$ & 87.153 & 0.067 & 0.158 & 1.00 & 4.1 & 1.08 & 0.05 & 35 \\
\hline $\mathbf{F}$ & 88.005 & 0.054 & 0.147 & 1.04 & 4.5 & 1.02 & 0.08 & 38 \\
\hline $\mathbf{G}$ & 89.004 & 0.300 & 0.070 & 2.53 & 4.8 & 0.90 & 0.30 & 43 \\
\hline $\mathbf{H}$ & 88.787 & 0.532 & 0.083 & 3.90 & 5.0 & 0.84 & 0.54 & 49 \\
\hline I & 87.565 & 0.812 & 0.102 & 5.05 & 5.4 & 0.82 & 0.62 & 54 \\
\hline SE \pm & 0.0002 & 0.0362 & 0.0033 & 0.041 & $\begin{array}{c}0.018 \\
3\end{array}$ & 0.0334 & 0.0338 & 0.182 \\
\hline C.D. at $5 \%$ & 0.0005 & 0.109 & 0.010 & 0.123 & 0.055 & 0.1004 & 0.1019 & 0.549 \\
\hline
\end{tabular}

Table.4 Comparative study of the quality parameters obtained for naturally fermented and controlled fermented Ginger ales

\begin{tabular}{|c|c|c|c|}
\hline Samples & $\begin{array}{c}\text { TSS } \\
\left({ }^{\mathbf{o}} \text { Brix }\right)\end{array}$ & $\begin{array}{c}\text { Specific } \\
\text { Gravity }\end{array}$ & $\begin{array}{c}\text { \% Alcohol } \\
(\mathbf{v} / \mathbf{v})\end{array}$ \\
\hline E & 13 & 1.052 & $\mathbf{0 . 5 0}$ \\
\hline F & 12 & 1.048 & $\mathbf{1 . 0 1}$ \\
\hline G & 10 & 1.040 & $\mathbf{1 . 5 3}$ \\
\hline H & 9 & 1.036 & $\mathbf{2 . 0 5}$ \\
\hline I & 8 & 1.032 & $\mathbf{2 . 5 7}$ \\
\hline SE \pm & 0.1826 & 0.0033 & $\mathbf{0 . 0 3 3 4}$ \\
\hline C.D. at 5\% & $\mathbf{0 . 5 4 9 6}$ & $\mathbf{0 . 0 0 9 9}$ & $\mathbf{0 . 1 0 0 4}$ \\
\hline
\end{tabular}

Table.5 Microbial count of fermenting mixture and Ginger ale from controlled fermentation

\begin{tabular}{|c|c|c|c|c|}
\hline $\begin{array}{c}\text { Period } \\
(\mathbf{d a y s})\end{array}$ & $\begin{array}{c}\text { Yeasts } \\
(\mathbf{c f u} / \mathbf{m l})\end{array}$ & $\begin{array}{c}\text { Moulds } \\
(\mathbf{c f u} / \mathbf{m l})\end{array}$ & $\begin{array}{c}\text { Aerobes } \\
(\mathbf{c f u} / \mathbf{m l})\end{array}$ & $\begin{array}{c}\text { LAB } \\
(\mathbf{c f u} / \mathbf{m l})\end{array}$ \\
\hline $\mathbf{0}$ & $6.5 \times 10^{5}$ & Absent & Nil & $\mathbf{8 . 8 \times 1 0 ^ { 3 }}$ \\
\hline $\mathbf{1}$ & $3.9 \times 10^{6}$ & Absent & $8.3 \times 10^{2}$ & $\mathbf{3 . 4} \times \mathbf{1 0}^{5}$ \\
\hline $\mathbf{2}$ & $5.8 \times 10^{7}$ & Absent & $1.6 \times 10^{3}$ & $\mathbf{3 . 4 \times 1 0 ^ { 5 }}$ \\
\hline $\mathbf{3}$ & $7.2 \times 10^{7}$ & Absent & $2.8 \times 10^{4}$ & $\mathbf{3 . 9} \times \mathbf{1 0}^{\mathbf{7}}$ \\
\hline $\mathbf{4}$ & $8.4 \times 10^{7}$ & Absent & $4.1 \times 10^{5}$ & $\mathbf{4 . 6 \times 1 0}$ \\
\hline $\mathbf{4}$ (pasteurized) & Absent & Absent & Absent & Absent \\
\hline
\end{tabular}


Fig.1 Process flow diagram for preparation of Ginger ale

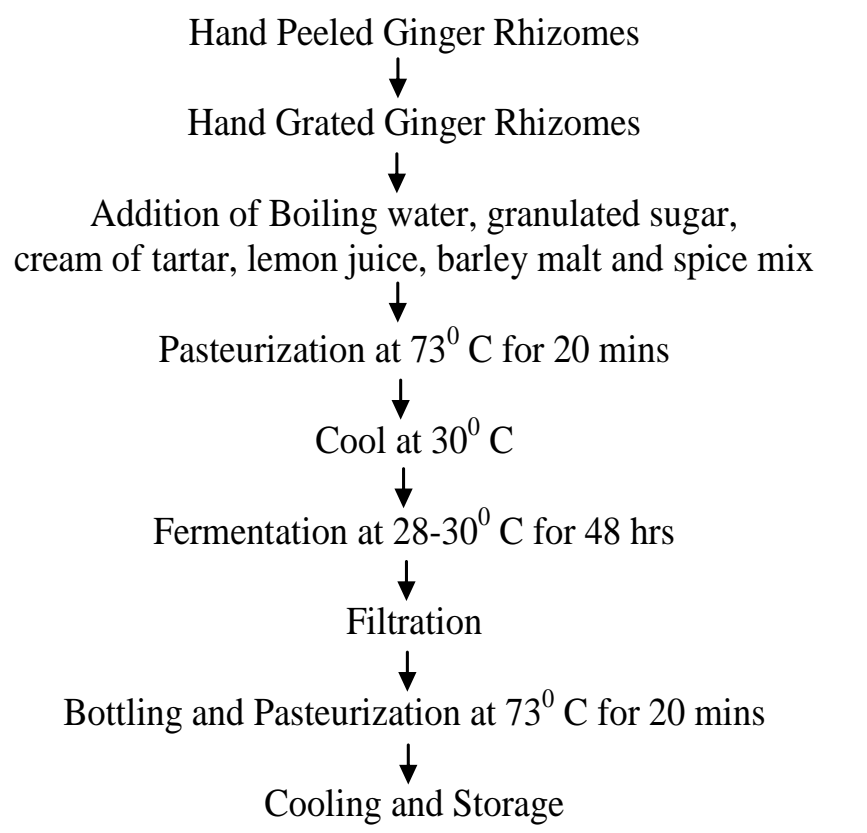

This study has drawn attention to the potential of ginger and malt in formulating nutritious health promoting beverage for the consumption of the Indian populace. Ginger had shown great potential as local substitute for hops. The controlled fermentation method for the production of the beverage was standardized. A good quality of Ginger ale can be prepared with 3\% ginger extract, $5 \%$ barley malt and $1 \%$ yeast. The prepared beverage was found to be nutritious, low in alcohol content and overall acceptable. It could also be concluded that the malting of barley grains increase the digestibility and bioavailability of all nutrients while lemon juice and spices improves the sensorial characteristics viz. flavour, taste and aroma of prepared beverage. Blending of ginger extract, malt, lemon juice and yeast helps in improving physico-chemical, organoleptic and keeping quality of beverage. Results obtained revealed that both chemical and microbiological characterization of the Ginger ale developed falls within the acceptable standard value and the analysis also reflects that the final product contained no harmful microorganisms or by-product. Therefore, this research work clearly shows that the development of ginger based unhopped ale is practically possible and profitable.

\section{References}

AOAC 1990. Official methods of analysis. Trends food science technology. Association of Official Analytical Chemists, Washington DC, USA.

Amerine MA, Kunkee RE, Ough CS, Singleton VL, Webb AD 1980. The technology of wine making. AVI Publishing Company Inc., Connecticut.

AOAC 1984. Official methods of analysis. Association of Official Analytical Chemists. Washington D.C.

AOAC 1970. Official methods of analysis, $10^{\text {th }}$ edn Association of Official Agricultural Chemist, Washington DC.

ASBC 1992. Methods of analysis. Association of Brewing Chemists. Washington D.C. 
Benítez E, Martinez AN, Sosa G, Peruchena N, Lozano J 2013. Turbidimetric behavior of colloidal particles in beer before filtration process. Food and Bioprocess Technology: An International Journal, 6, 1082-1090.

Berry DR 1995.Yeasts. In Lea, A.G.H. and Piggot, J.R. (eds). Fermented beverages production. Blackie Academic and Professional, London.

Downes FP, Ito K 2001. Compendium of methods for the microbiological examination of foods. America Public Health Association. Washington D.C.

Fleet C, Siebert K 2005. Effect of illumination intensity on visual perception of turbidity. Food Quality and Preference, 16, 536-544.

Jayashree E, Kandiannan K, Prasath D, Rashid P, Sasikumar B, Senthil CM 2014. ICAR-Indian Institute of Spices Research (Indian Council of Agricultural Research) Kozhikode, Kerala.

Koekemoer, Adelakun OE, Oyelade OJ, AdeOmowaye BIO, Adeyemi IA, Vanderventer M 2009. Influence of pre-treatment on physicochemical and functional properties of a Nigeria okro seed (Abelmoschus esculentus moench) flour. Food and Chemical Toxicology (47) 657-661.
Lewis MJ, Young TW 1995. Brewing. Chapman and Hall, London.

McCloskey LP 1978. Enzymatic analysis for glucose and fructose. Am. J. Enol. Vitic. 29(3):226-227.

Oluwaniyi OO, Dosumu OO, Awolola GV, Abdulraheem AF 2009. Nutritional Analysis and Stability Studies of Some Natural and Synthetic Food Colourants American Journal of Food Technology 4(5): 218-225.

Osuntogun B, Aboaba O 2004. Microbiological and Physicochemical Evaluation of some nonalcoholic Beverages. Pakistan Journal of Nutrition, 3:188-192.

Ough CS, Amerine MA 1988. Methods for analysis of musts and wines. John Wiley and Sons, New York.

Pambianchi D 1999. Techniques in home winemaking: A practical guide to making chateau-style wines. Vehicule Press. Montreal.

Rahman S 2010. Handbook of Food Preservation. CRC Press. 2007. p. 221.

Salunkhe PY 2014. Ginger cultivation in Satara district: A Geographical Analysis. International Journal of Advance and Applied Research (IJAAR), 1(3):1-11.

\section{How to cite this article:}

Deshpande, H.W., Mukesh Belwal, S.D. Katke and Tamboli, N.M. 2019. Studies on Process Standardization and Quality Evaluation of Ginger Ale. Int.J.Curr.Microbiol.App.Sci. 8(07): 1043-1050. doi: https://doi.org/10.20546/ijcmas.2019.807.125 